\section{Effect of Fermented Millet Flour Ibyer Supplemented with Ginger Powder on Hematological Indices and Body Weight of Wister Albino Rats}

\begin{abstract}
Adakole Maria Eji', Ikya Julius Kwagh-Hal', Girgih Abraham Tartenger ${ }^{1}$, Ogori Akama Friday ${ }^{1,2 *}$ and Upev Vincent ${ }^{3}$
\end{abstract}

${ }^{1}$ Department of Food Science and Technology, Federal University of Agriculture, Makurdi, Benue State, Nigeria

${ }^{2}$ Department of Home Science and Management, Faculty of Agriculture, Federal University Gashua, Yobe State, Nigeria

${ }^{3}$ Department of Veterinary Physiology, Federal university of Agriculture Makurdi, Beneu State, Nigeria

\begin{abstract}
In this study, fermented millet flour supplemented with ginger powder were formulated in the ratio $100 \%$ millet flour: $0 \%$ ginger flour, $95 \%$ millet flour: $5 \%$ ginger flour, $90 \%$ millet flour: $10 \%$ ginger flour, $85 \%$ millet flour: $15 \%$ ginger flour, $80 \%$ millet flour: $20 \%$ ginger flour, $75 \%$ millet flour: $25 \%$ ginger flour, and $70 \%$ millet flour: $30 \%$ ginger flour respectively for the production of "Ibyer". The blends were subjected to feeding trial using male wistar albino rats of 3 weeks old, weighing $100 \mathrm{~g}$ to $130 \mathrm{~g}$ obtained. They were fed formulated diet prepared from fermented millet flour and ginger powder blends. The hematological analysis showed that packed cell volume ranged from $32-54 \%$, white blood cell ranged from $1.87-7.10 \times 10^{9} / \mathrm{L}$ and red blood cell ranged from $4.20-6.97 \times 10^{12} / \mathrm{L}$ which was within recommended range. The albino rats showed significant increase in body weight throughout the experimental periodranging from 78.67 - $103.80 \mathrm{~g}$. The result from the experimental analysis finally revealed that 'Ibyer', A fermented millet flour blended with ginger at ration $85 \%$ millet flour: $15 \%$ ginger flour, $80 \%$ millet flour: $20 \%$ ginger flour, $75 \%$ millet flour: $25 \%$ ginger flour had better heamatological indices.
\end{abstract}

Keywords: Albino rat; Body weight; Fermented; Ginger flour; Hematology; Millet flour; Supplementation

*Corresponding author: Ogori Akama Friday, Department of Home Science and Management, Faculty of Agriculture, Federal University, Gashua, P.M.B.1005 Gashua, Yobe State, Nigeria, Email: ogorifaraday@gmail.com

Citation: Eji AM, Kwagh-Hal IJ, Tartenger GA, Friday OA, Vincent U (2020) Effect of Fermented Millet Flour Ibyer Supplemented with Ginger powder on Hematological Indices and Body Weight of Wister Albino Rats. J Protein Res Bioinform 2: 013.

Received: September 29, 2020; Accepted: October 19, 2020; Published: October 26, 2020

Copyright: @ $2020 \mathrm{Eji} \mathrm{AM}$, et al. This is an open-access article distributed under the terms of the Creative Commons Attribution License, which permits unrestricted use, distribution, and reproduction in any medium, provided the original author and source are credited.

\section{Introduction}

"Ibyer" is indigenous to the Tiv people in Benue state andhas similar characteristics to some gruels in certain localities in Nigeria and Africa, as an example is Eniokwola a porridge eaten by the Idoma people of Benue state [1]. Two types of ibyerare consumed based on the method of preparation. The sweet type (Ibyer-i-nyohon), prepared by milling the grain into flour which is reconstituted with water and cooked [2] while the sour type (Ibyer-angen) undergoes fermentation. The powder I for the sour type isreconstituted to form a slurry or paste which is left to ferment overnight thus producing the desired sourness [1].

Millet is an important security crop but it is not popular in Nigeria. Millet is an important minor cereal crop with very high nutritional and medicine values. These are attributed to its high polyphenol, dietary fiber, minerals and essential amino acids [3]. Millets lack gluten and can be consumed by people suffering from celiac disease [4]. Some in vivo studies by [5-8], showed significant lowering of blood glucose level by millet based diet when compared to a wheat or rice diet. However, most of the in vivo studies on millets have mainly considered millets products from composite flour. Epidemiological studies indicates that regular consumption of whole grain and their products can protect against the risk of cardiovascular diseases, type II diabetes, obesity, gastrointestinal cancers and atherosclerogenic effects, anti-oxidant and microbial properties and so many other disorders $[3,9,10]$ reported that millet contain high level of methionine, tryptophan, vitamin B, fiber and minerals such as phosphorus, iron and it contains forty times calcium level more than that found in maize (Zea mays L.) and rice (Oryza sativa L.) and contain ten times calcium more than that found in wheat (Triticumestivum L.). Millets are known to have a low glycemic index as suggested by some in vivo studies however all of these studies have mainly focused on millet products from composite flour [6-8]. Starch digestibility studies on the $100 \%$ cooked millet flour have been rarely done. Dietary fibre, phenolics and lipids which are mainly lost during decortication may also affect in vitro starch digestibility $[11,12]$.

Fermentation can synthesize certain amino acids and increase availability of vitamins [13]. It also sets optimum $\mathrm{pH}$ conditions for enzymatic degradation of phytate which is present in millets as complexes with polyvalent cations such as iron, zinc, calcium, magnesium and proteins. The reduction in phytate may increase the amount of soluble iron, zinc and calcium in many folds [14]. Improvement of starch, protein digestibility and sensory properties of food products from fermented and germinated flour has also been reported [15].

Ginger can be used fresh, dried, powdered, or as an oil or juice, and is sometimes added to processed foods and cosmetics. It is a very common ingredient in recipes. The unique fragrance and flavor of ginger come from its natural oils, the most important of which is gingerol. Gingerol is the main bioactive compound in ginger, responsible for much of its medicinal properties. It has powerful antiinflammatory and antioxidant effects [16]. 
Citation: Eji AM, Kwagh-Hal IJ, Tartenger GA, Friday OA, Vincent U (2020) Effect of Fermented Millet Flour Ibyer Supplemented with Ginger powder on Hematological Indices and Body Weight of Wister Albino Rats. J Protein Res Bioinform 2: 013.

The medicinal, chemical, and pharmacological properties of ginger have been extensively reviewed [17]. Over the last few years, interest in ginger or its various components as valid preventive or therapeutic agents has increased markedly, and scientific studies focusing on verification of ginger's pharmacological and physiological actions have likewise increased [16]. The present study was aimed at assessing the quality of fermented millet (Pennisetumglacum) flour supplemented with ginger (Zingiber officinalis) powder and its effect on haematological indices and body weight of albino rats.

\section{Materials and Methodology}

\section{Sample preparation}

The milletgrains weresorted and milled into flourusinghammer mills.

\section{Preparation of fermented millet flour}

The method described by [18] was used with slight modifications for the production of millet flour. Pearl millet flour was prepared as shown in (Figure 1). The grains were sorted and cleaned to remove unwanted materials like stones, pebbles and other foreign seeds, before washing with tap water and steeping $(72 \mathrm{~h})$. Therefore, the grains were drained, dried, milledand sieved to get whole pearl millet flour.

$$
\begin{aligned}
& \text { MILLT GRAINS } \\
& \text { Sorting } \\
& \text { Milling (hantmer mill) } \\
& \text { Sieving (in clean water) } \\
& \text { Millet flour }
\end{aligned}
$$

Figure 1: Flow chart for the production of millet flour Source: [18].

\section{Preparation of ginger powder}

Ginger flour will be prepared according to the method of [19] with slight modification as shown in (Figure 2). Fresh ginger roots were sorted by soaking in water to get rid of dirts and to remove unwanted materials, before washing with tap water. The cleaned roots were drained, sliced, and sundried, milled using hammer milland sieved through $600 \mu \mathrm{m}$ aperture size.

\section{Preparation of "ibyer" from fermented millet flour and ginger powder blends}

'Ibyer' was produced as described by [20] with slight modification. Each sample weighing 100:0, 95:5, 90:10, 85:15,80:20, 75:25, 70:30 (Table 1) of both fermented millet flour and ginger powder were mixed each with $10 \mathrm{ml}$ of distilled water to form a slurry. It was allowed to ferment for $12 \mathrm{~h}$. $200 \mathrm{ml}$ of boiling water was added to the slurry which was heated for 10 minutes with continuous stirring to avoid the formation of lumps. The gruel was allowed to cool to $40^{\circ} \mathrm{C}$ The production flow chart is as shown in (Figure 3).

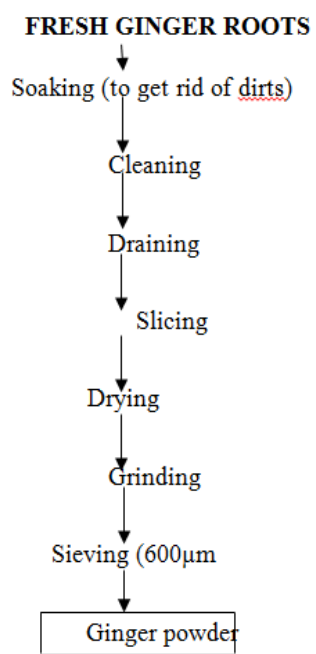

Figure 2: Flow chart for the production of ginger powderSource: [19] Modified.

\begin{tabular}{|c|c|c|}
\hline Sample code & Millet & Ginger \\
\hline 716 & 100 & - \\
\hline 924 & 95 & 5 \\
\hline 839 & 90 & 10 \\
\hline 746 & 85 & 15 \\
\hline 958 & 80 & 20 \\
\hline 469 & 75 & 25 \\
\hline 577 & 70 & 30 \\
\hline
\end{tabular}

Table 1: Blend Formulation (\%) of fermented millet flour supplemented with ginger powder for "ibyer"production.

Key: $716=\mathrm{M}_{100}$ (Control), $924=\mathrm{M}_{95} \mathrm{G}_{5}, 839=\mathrm{M}_{90} \mathrm{G}_{10}, 746=\mathrm{M}_{85} \mathrm{G}_{15}, 958=\mathrm{M}_{80} \mathrm{G}_{20}, 469=\mathrm{M}_{75}$ $\mathrm{G}_{25}, 577=\mathrm{M}_{70} \mathrm{G}_{30}$

Where, $\mathrm{M}=$ Millet, $\mathrm{G}=$ Ginger

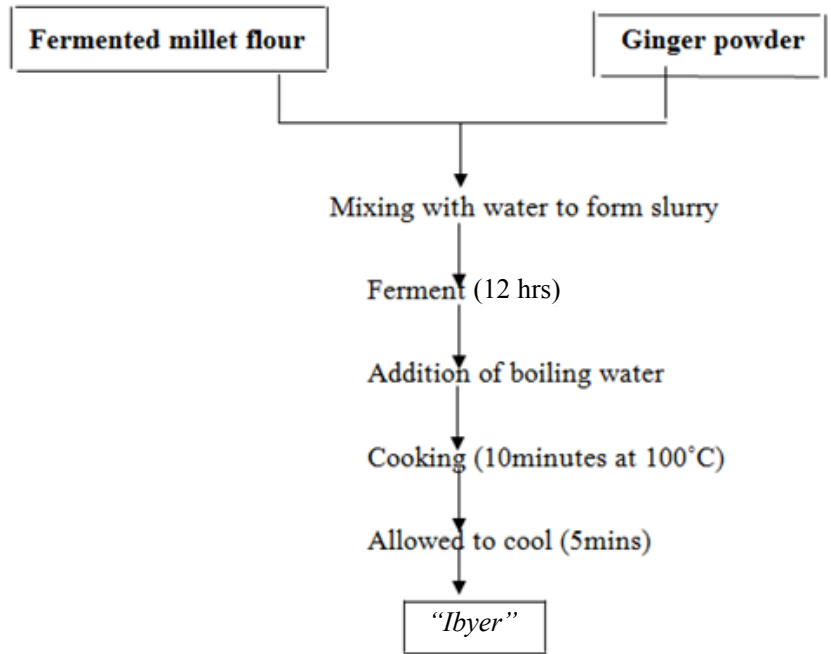

Figure 3: Flow chart for the production of "ibyer"Source: [20]. 
Citation: Eji AM, Kwagh-Hal IJ, Tartenger GA, Friday OA, Vincent U (2020) Effect of Fermented Millet Flour Ibyer Supplemented with Ginger powder on Hematological Indices and Body Weight of Wister Albino Rats. J Protein Res Bioinform 2: 013.

\section{Experimental animals' model and their maintenance}

Twenty-one (21) healthy wistar albino rats aged 3 weeks (21days), weighing $100 \mathrm{~g}$ to $130 \mathrm{~g}$ were obtained from Benue state university, college of health science. Three rats were kept in animal cages in an animal house Department of Home Science and Management, Federal University of Agriculture, Makurdi. The rats wereallowed to acclimatize with the laboratory condition for 7 days in well ventilated cages. They were divided into 7 groups of 3 rats each. Each of the rats was given an identification mark in form of an indelible mark on tail, head and back. During the acclimatization period, the rats were allowed access to food and water ad libitum (Table 2).

\begin{tabular}{|c|c|c|c|c|c|c|c|}
\hline Sample code & 716 & 924 & 839 & 746 & 958 & 469 & 577 \\
\hline Millet & 10 & 9.5 & 9 & 8.5 & 8 & 7.5 & 7 \\
\hline Ginger & - & 0.5 & 1 & 1.5 & 2 & 2.5 & 3 \\
\hline Corn starch & 70 & 70 & 70 & 70 & 70 & 70 & 70 \\
\hline Vitalyte & 5 & 5 & 5 & 5 & 5 & 5 & 5 \\
\hline Rice husk & 5 & 5 & 5 & 5 & 5 & 5 & 5 \\
\hline Sucrose & 10 & 10 & 10 & 10 & 10 & 10 & 10 \\
\hline Total & 100 & 100 & 100 & 100 & 100 & 100 & 100 \\
\hline
\end{tabular}

Key: $716=\mathrm{M}_{100}$ (Control), $924=\mathrm{M}_{95} \mathrm{G}_{5}, 839=\mathrm{M}_{90} \mathrm{G}_{10}, 746=\mathrm{M}_{85} \mathrm{G}_{15}, 958=\mathrm{M}_{80} \mathrm{G}_{20}$, $469=\mathrm{M}_{75} \mathrm{G}_{25}, 577=\mathrm{M}_{70} \mathrm{G}_{30}$.

Where, $\mathrm{M}=$ Millet, $\mathrm{G}=$ Ginger

\section{Methodology}

\section{Specimen collection and preservation}

About $1.5-2 \mathrm{ml}$ of blood was directly collected through intracardiac puncture with a hypodermic syringe to minimize damage and serum contamination [21] at day 3,7,14,21 and 28. Application of finger pressure is necessary to dilate the vessel. Blood was withdrawn slowly to prevent the vessel collapsing. The collected blood was split into two aliquot; one portion was of $500 \mu \mathrm{l}$ in heparinized microhaematocrit tubes for estimation of packed cell volume (PCV), Red blood cell (RBC) and White Blood Cell (WBC). The rest of the blood was used for serum isolation according to the method of [22]. The blood was kept under room temperature in a little slanting condition at $30^{\circ} \mathrm{C}$ when centrifuged at $2500 \mathrm{rpm}$ for 10 minutes. The supernatant was obtained as serum and kept at $4^{\circ} \mathrm{C}$ for further determination of serum total protein, alanine amino transferase (ALT), aspartate amino transferase (AST) and Total Cholesterol. At the end of the experimental period, each animal was sacrificed by decapitation, and their organs were weighed in terms of size, weight and color.

\section{Packed Cell Volume (PCV)}

Blood sample was filled to $75 \%$ of capillary tube through capillary action, one end of tube was sealed with plasticine and placed in micro-haematocrit centrifuge and the centrifuge was set at $12 \mathrm{rpm}$ (revolution per minute) for 5 minutes. There after, the centrifuge was spuned and the tubes were removed and the percentage packed volume was read using micro-haematocrit reader according to the method of [23].

\section{Red Blood Cells (RBC)}

The red blood cells count was determined by haemocytometry.

Procedure: Blood was drawn up to 0.5 mark of the RBC pipette and RBC diluting fluid was added to it up to 101 marks. The fluid and blood were mixed well and the first few drops of blood were discarded by holding the pipette vertically. The counting chamber was charged with a drop of blood that had mixed with diluting fluid and the chamber was left undisturbed for few minutes and the four corners of the chamber were visualized under a low power (10x) objective and cells were counted in all the four marked squares.

\section{Total $\mathrm{RBC} / \mathrm{L}=\overline{\text { Number of cells counted } \mathrm{x} \text { diluting factor }}$ Area counted $\mathrm{x}$ depth of fluid}

\section{White Blood Cells (WBC) or Total Leucocyte Count (TLC)}

Total leucocyte count was determined by haemocytometer method

Procedure: Blood was drawn up to 0.5 mark of the WBC pipette and WBC diluting fluid was added up to 11 mark. The fluid and blood were mixed well and the first few drops of blood were discarded by holding the pipette vertically. The counting chamber was charged by holding the pipette vertically. The counting chamber was charged with a drop of blood that has mixed with diluting fluid and the chamber was left undisturbed for few minutes and the four corners of the chamber and the middle were visualized under a low power (10x) objective and cells were counted in all the four marked squares. $\begin{aligned} \text { Total WBC/L }= & \overline{\text { Number of cells } \mathrm{x} \text { diluting factor }} \\ & \text { Area counted } \mathrm{x} \text { depth of fluid }\end{aligned}$

\section{Results}

Packed cell volume (\%) of the experimental albino rats fed fermented millet flour supplemented with ginger powder. The Packed Cell Volume (PCV) in (Table 3) shows that there was a significant increase from the initial to Day 14 in all the experimental groups apart from the control sample which decreased from day 3 to day 28. On the other hand, the PCV after alloxan induction decreased on day 21 in all the experimental groups because of the effect of alloxan monohydrate and increased on day 28 which shows that the experimental animals were utilizing their diet well and the animals were not anaemic during the experiment because their PCV was within the recommended range (28-50\%).

\section{Red blood cells $\left(10^{12} / \mathrm{L}\right)$ of the experimental albino rats fed fermented millet flour supplemented with ginger powder}

The (Table 4) shows that Red Blood Cell (RBC) of all the experimental groups significantly increased $(\mathrm{p}<0.05)$ from day 3 to day 14 of the normal feeding trial as compared to the baseline of the experiment indicating the animals were healthy. However, there was a significant decrease $(\mathrm{p}<0.05)$ in the RBC on day 21 after alloxan induction and an increase on day 28 while the control group (716) decreased from the initial to the day 28All the values were within the recommended range $3-11 \times 10^{12} / \mathrm{L}$. 
Citation: Eji AM, Kwagh-Hal IJ, Tartenger GA, Friday OA, Vincent U (2020) Effect of Fermented Millet Flour Ibyer Supplemented with Ginger powder on Hematological Indices and Body Weight of Wister Albino Rats. J Protein Res Bioinform 2: 013.

\begin{tabular}{|c|c|c|c|c|c|c|}
\hline \multirow{2}{*}{ Sample code } & \multicolumn{3}{|c|}{ Packed Cell Volume (PCV) } & \multicolumn{3}{c|}{ After alloxan induction } \\
\cline { 2 - 7 } & Initial & Day 3 & Day 7 & Day 14 & Day 21 & Day 28 \\
\hline 716 & $40.67 \pm 1.45^{\mathrm{a}}$ & $39.67 \pm 3.38^{\mathrm{a}}$ & $36.67 \pm 3.33^{\mathrm{a}}$ & $34.67 \pm 2.19^{\mathrm{b}}$ & $33.00 \pm 1.15^{\mathrm{a}}$ & $32.6 \pm 0.88^{\mathrm{a}}$ \\
\hline 924 & $38.33 \pm 2.60^{\mathrm{a}}$ & $38.93 \pm 1.15^{\mathrm{a}}$ & $48.67 \pm 4.97^{\mathrm{a}}$ & $49.67 \pm 2.18^{\mathrm{b}}$ & $36.00 \pm 1.15^{\mathrm{a}}$ & $39.3 \pm 2.07^{\mathrm{c}}$ \\
\hline 839 & $39.67 \pm 3.84^{\mathrm{a}}$ & $40.00 \pm 3.06^{\mathrm{a}}$ & $49.33 \pm 1.20^{\mathrm{ab}}$ & $50.67 \pm 2.18^{\mathrm{b}}$ & $37.70 \pm 1.20^{\mathrm{a}}$ & $38.6 \pm 0.33^{\mathrm{bc}}$ \\
\hline 746 & $40.00 \pm 3.51^{\mathrm{a}}$ & $41.33 \pm 3.71^{\mathrm{a}}$ & $42.00 \pm 7.93^{\mathrm{a}}$ & $45.33 \pm 1.46^{\mathrm{b}}$ & $37.70 \pm 3.17^{\mathrm{a}}$ & $37.7 \pm 0.88^{\mathrm{bc}}$ \\
\hline 958 & $41.00 \pm 0.57^{\mathrm{a}}$ & $42.33 \pm 0.33^{\mathrm{a}}$ & $44.00 \pm 2.00^{\mathrm{ab}}$ & $49.00 \pm 1.52^{\mathrm{bc}}$ & $35.00 \pm 4.33^{\mathrm{a}}$ & $38.3 \pm 1.20^{\mathrm{bc}}$ \\
\hline 469 & $41.00 \pm 1.52^{\mathrm{a}}$ & $41.67 \pm 1.20^{\mathrm{a}}$ & $50.67 \pm 2.33^{\mathrm{ab}}$ & $54.00 \pm 1.52^{\mathrm{bc}}$ & $36.60 \pm 0.88^{\mathrm{a}}$ & $37.3 \pm 1.20^{\mathrm{bc}}$ \\
\hline 577 & $40.00 \pm 2.89^{\mathrm{a}}$ & $40.67 \pm 1.76^{\mathrm{a}}$ & $46.67 \pm 2.33^{\mathrm{ab}}$ & $47.33 \pm 4.97^{\mathrm{ab}}$ & $36.60 \pm 0.88^{\mathrm{a}}$ & $37.3 \pm 3.28^{\mathrm{ab}}$ \\
\hline
\end{tabular}

Table 3: Packed cell volume (\%) of the experimental albino rats fed fermented millet flour supplemented with ginger powder.

Values are mean $\pm S D$ of 3 replicate determinant, $n=3$; values bearing different superscripts $(a, b, c)$ in the same row are significantly ( $<<0.05$ ) different; PCV=Packed Cell Volume

KEY: $716=\mathrm{M}_{100}$ (control), $924=\mathrm{M}_{95} \mathrm{G}_{5}, 839=\mathrm{M}_{90} \mathrm{G}_{10}, 746=\mathrm{M}_{85} \mathrm{G}_{15}, 958=\mathrm{M}_{80} \mathrm{G}_{20}, 469=\mathrm{M}_{75} \mathrm{G}_{25}, 577=\mathrm{M}_{70} \mathrm{G}_{30}$

Where, $\mathrm{M}=$ Millet, $\mathrm{G}=$ Ginger

\begin{tabular}{|c|c|c|c|c|c|c|}
\hline \multirow{2}{*}{ Sample code } & \multicolumn{3}{|c|}{ Red Blood Cell $(\mathrm{RBC}) \times 10_{12^{\prime}} \mathrm{L}$} & \multicolumn{3}{c|}{ After alloxan induction } \\
\cline { 2 - 7 } & Initial & Day 3 & Day 7 & Day 14 & Day 21 & Day 28 \\
\hline 716 & $5.10 \pm 0.15^{\mathrm{a}}$ & $4.83 \pm 0.32^{\mathrm{a}}$ & $4.76 \pm 0.12^{\mathrm{a}}$ & $4.61 \pm 0.06^{\mathrm{b}}$ & $5.40 \pm 0.05^{\mathrm{c}}$ & $4.86 \pm 0.03^{\mathrm{b}}$ \\
\hline 924 & $5.23 \pm 0.38^{\mathrm{a}}$ & $5.36 \pm 0.37^{\mathrm{a}}$ & $5.97 \pm 0.31^{\mathrm{bc}}$ & $6.50 \pm 0.17^{\mathrm{b}}$ & $4.80 \pm 0.05^{\mathrm{b}}$ & $5.00 \pm 0.11^{\mathrm{b}}$ \\
\hline 839 & $5.83 \pm 0.58^{\mathrm{a}}$ & $5.93 \pm 0.55^{\mathrm{a}}$ & $6.77 \pm 0.18^{\mathrm{d}}$ & $6.97 \pm 0.2^{\text {obc }}$ & $5.00 \pm 0.11^{\mathrm{bc}}$ & $5.46 \pm 0.14^{\mathrm{b}}$ \\
\hline 746 & $5.46 \pm 0.48^{\mathrm{a}}$ & $5.53 \pm 0.12^{\mathrm{a}}$ & $5.53 \pm 0.26^{\mathrm{a}}$ & $6.10 \pm 0.15^{\mathrm{c}}$ & $4.80 \pm 0.28^{\mathrm{b}}$ & $4.90 \pm 0.11^{\mathrm{b}}$ \\
\hline 958 & $5.10 \pm 0.12^{\mathrm{a}}$ & $5.10 \pm 0.25^{\mathrm{a}}$ & $5.46 \pm 0.26^{\mathrm{a}}$ & $5.83 \pm 0.20^{\mathrm{bc}}$ & $4.63 \pm 0.31^{\mathrm{ab}}$ & $4.80 \pm 0.41^{\mathrm{b}}$ \\
\hline 469 & $5.10 \pm 0.55^{\mathrm{a}}$ & $5.16 \pm 0.44^{\mathrm{a}}$ & $6.46 \pm 0.14^{\text {cd }}$ & $6.67 \pm 0.24^{\mathrm{b}}$ & $4.20 \pm .11^{\mathrm{a}}$ & $4.37 \pm 0.27^{\mathrm{a}}$ \\
\hline 577 & $5.53 \pm 0.28^{\mathrm{a}}$ & $5.64 \pm 0.20^{\mathrm{a}}$ & $6.30 \pm 0.12^{\text {cd }}$ & $6.30 \pm 0.17^{\mathrm{b}}$ & $4.87 \pm 0.08^{\mathrm{bc}}$ & $4.97 \pm 0.35^{\mathrm{b}}$ \\
\hline
\end{tabular}

Table 4: Red blood cells $\left(10^{12} / \mathrm{L}\right)$ of the experimental albino rats fed fermented millet flour supplemented with ginger powder.

Values are mean $\pm \mathrm{SD}$ of 3 replicate determinant, $\mathrm{n}=3$; values bearing different superscripts $(\mathrm{a}, \mathrm{b}, \mathrm{c})$ in the same row are significantly ( $<<0.05$ ) different.

KEY: $716=\mathrm{M}_{100}$ (control), $924=\mathrm{M}_{95} \mathrm{G}_{5}, 839=\mathrm{M}_{90} \mathrm{G}_{10}, 746=\mathrm{M}_{85} \mathrm{G}_{15}, 958=\mathrm{M}_{80} \mathrm{G}_{20}, 469=\mathrm{M}_{75} \mathrm{G}_{25}, 577=\mathrm{M}_{70} \mathrm{G}_{30}$

Where, $\mathrm{M}=$ Millet, $\mathrm{G}=$ Ginger

\section{White blood cells $\left(10^{9} / \mathrm{L}\right)$ of the experimental albino rats fed fermented millet flour supplemented with ginger pow- der}

The White Blood Cells (WBC) in (Table 5) shows a slight increase in all the groups from day 3 to day 14 of the normal feeding trial as compared to the baseline while the control group was unstable. However, there was a significant decrease in WBC on day 21 after alloxan induction in all the groups indicating the animals were diseased. On day 28 after the treatment with the diet, there was a slight increase in white blood cells proliferation showing that the diet had positive effect on the animals. All the values obtained were within the recommended range of $2-9 \times 10^{9} / \mathrm{L}$.

\section{Body weight (g) of the experimental animals fed fermented millet flour supplemented with ginger powder}

Body weight indicates the normal growth of the rats. The (Table 6) shows that the animals exhibited slight increase in body weight on day 7 to day 14 when the normal feeding trial was terminated in all the groups. However, there was a significant $(\mathrm{p}<0.05)$ decrease in body weight on day 21 during alloxan induction.

There is also a significant increase $(\mathrm{p}<0.05)$ in body weight on day 28 showing that the experimental animals were utilizing their diet well and its attributed to the normal growth of the rats.

\section{Discussion}

Packed cell volume of experimental albino rats fed fermented millet flour supplemented with ginger powder Packed Cell Volume (PCV) is a test that indicates whether someone is anaemic. Packed Cell Volume is used to measure red blood cell mass. From (Table 4), an increase in red blood cell mass is equivalent to erythrocytosis and a decrease indicating anaemia. Results of the PCV showed that the PCV increased from day 3 to day 14 which indicate that the experimental animals were utilizing their diet well while the PCV in the control sample decreased from day 3 to day 28 . The PCV reduced at day 21 when alloxan was induced. Alloxan is a toxic chemical which is used for induction of diabetes in experimental animals. At day 28 the PCV increased which indicate the animals were utilizing their diet well.

\section{Red Blood Cells of experimental albino rats fed fermented millet flour supplemented with ginger powder}

The red blood cell carries oxygen. The result from (Table 4) shows an increase in RBC from day 3 to day 14 indicating the rats were utilizing their diet well. At day 21 when alloxan was induced the red blood cells reduced due to the effect of the alloxan and increased on day 28 because of the ameliorative effect of the diet on the albino rats. The control sample decreased from day 3 to day 28 . This report agrees with the report of [24] that worked on haematological parameters of alloxan- induced diabetic rats treated with leaf essential oil of Hoslundia opposite. 
Citation: Eji AM, Kwagh-Hal IJ, Tartenger GA, Friday OA, Vincent U (2020) Effect of Fermented Millet Flour Ibyer Supplemented with Ginger powder on Hematological Indices and Body Weight of Wister Albino Rats. J Protein Res Bioinform 2: 013.

\begin{tabular}{|c|c|c|c|c|c|c|}
\hline \multirow{2}{*}{ Sample code } & \multicolumn{3}{|c|}{ Red Blood Cell $\left(\right.$ RBC) $\times 10^{12} / \mathrm{L}$} & \multicolumn{3}{c|}{ After alloxan induction } \\
\cline { 2 - 7 } & Initial & Day 3 & Day 7 & Day 14 & Day 21 & Day 28 \\
\hline 716 & $5.10 \pm 0.15^{\mathrm{a}}$ & $4.83 \pm 0.32^{\mathrm{a}}$ & $4.76 \pm 0.12^{\mathrm{a}}$ & $4.61 \pm 0.06^{\mathrm{b}}$ & $5.40 \pm 0.05^{\mathrm{c}}$ & $4.86 \pm 0.03^{\mathrm{b}}$ \\
\hline 924 & $5.23 \pm 0.38^{\mathrm{a}}$ & $5.36 \pm 0.37^{\mathrm{a}}$ & $5.97 \pm 0.31^{\mathrm{bc}}$ & $6.50 \pm 0.17^{\mathrm{b}}$ & $4.80 \pm 0.05^{\mathrm{b}}$ & $5.00 \pm 0.11^{\mathrm{b}}$ \\
\hline 839 & $5.83 \pm 0.58^{\mathrm{a}}$ & $5.93 \pm 0.55^{\mathrm{a}}$ & $6.77 \pm 0.18^{\mathrm{d}}$ & $6.97 \pm 0.20^{\mathrm{bc}}$ & $5.00 \pm 0.11^{\mathrm{bc}}$ & $5.46 \pm 0.14^{\mathrm{b}}$ \\
\hline 746 & $5.46 \pm 0.48^{\mathrm{a}}$ & $5.53 \pm 0.12^{\mathrm{a}}$ & $5.53 \pm 0.26^{\mathrm{a}}$ & $6.10 \pm 0.15^{\mathrm{c}}$ & $4.80 \pm 0.28^{\mathrm{b}}$ & $4.90 \pm 0.11^{\mathrm{b}}$ \\
\hline 958 & $5.10 \pm 0.12^{\mathrm{a}}$ & $5.10 \pm 0.25^{\mathrm{a}}$ & $5.46 \pm 0.26^{\mathrm{a}}$ & $5.83 \pm 0.20^{\mathrm{bc}}$ & $4.63 \pm 0.31^{\mathrm{ab}}$ & $4.80 \pm 0.41^{\mathrm{b}}$ \\
\hline 469 & $5.10 \pm 0.55^{\mathrm{a}}$ & $5.16 \pm 0.44^{\mathrm{a}}$ & $6.46 \pm 0.14^{\mathrm{cd}}$ & $6.67 \pm 0.24^{\mathrm{b}}$ & $4.20 \pm 0.11^{\mathrm{a}}$ & $4.37 \pm 0.27^{\mathrm{a}}$ \\
\hline 577 & $5.53 \pm 0.28^{\mathrm{a}}$ & $5.64 \pm 0.20^{\mathrm{a}}$ & $6.30 \pm 0.12^{\mathrm{cd}}$ & $6.30 \pm 0.17^{\mathrm{b}}$ & $4.87 \pm 0.08^{\mathrm{bc}}$ & $4.97 \pm 0.35^{\mathrm{b}}$ \\
\hline
\end{tabular}

Table 5: White blood cells $\left(10^{9} / \mathrm{L}\right)$ count of the experimental albino rats fed fermented millet flour supplemented with ginger powder.

Values are mean $\pm \mathrm{SD}$ of 3 replicate determinant, $\mathrm{n}=3$; values bearing different superscripts $(\mathrm{a}, \mathrm{b}, \mathrm{c})$ in the same row are significantly ( $\mathrm{p}<0.05$ ) different. KEY: $716=\mathrm{M}_{100}$ (control), $924=\mathrm{M}_{95} \mathrm{G}_{5}, 839=\mathrm{M}_{90} \mathrm{G}_{10}, 746=\mathrm{M}_{85} \mathrm{G}_{15}, 958=\mathrm{M}_{80} \mathrm{G}_{20}, 469=\mathrm{M}_{75} \mathrm{G}_{25}, 577=\mathrm{M}_{70} \mathrm{G}_{30}$ Where, $\mathrm{M}=$ Millet, $\mathrm{G}=$ Ginger

\begin{tabular}{|c|c|c|c|c|c|}
\hline \multirow{2}{*}{ Sample code } & \multicolumn{3}{|c|}{ Body Weights } & \multicolumn{2}{c|}{ After alloxan induction } \\
\cline { 2 - 6 } & Initial & Day 7 & Day 14 & Day 21 & Day 28 \\
\hline $\mathrm{M}_{100}$ & $95.37 \pm 5.16^{\text {ab }}$ & $96.67 \pm 4.33^{\text {bc }}$ & $97.40 \pm 3.08^{\text {abc }}$ & $95.30 \pm 2.10^{\mathrm{b}}$ & $98.60 \pm 3.18^{\mathrm{a}}$ \\
\hline $\mathrm{M}_{95} \mathrm{G}_{5}$ & $78.67 \pm 1.45^{\mathrm{a}}$ & $84.56 \pm 2.02^{\mathrm{ab}}$ & $88.00 \pm 1.15^{\text {abc }}$ & $87.20 \pm 1.10^{\mathrm{b}}$ & $87.90 \pm 2.12$ \\
\hline $\mathrm{M}_{90} \mathrm{G}_{10}$ & $83.00 \pm 1.15^{\mathrm{a}}$ & $87.67 \pm 1.45$ & $89.00 \pm 1.25^{\mathrm{abc}}$ & $88.40 \pm 1.15^{\mathrm{b}}$ & $88.80 \pm 1.18$ \\
\hline $\mathrm{M}_{85} \mathrm{G}_{15}$ & $100.23 \pm 6.93^{\mathrm{c}}$ & $101.67 \pm 4.91$ & $103.80 \pm 5.24^{\mathrm{bc}}$ & $93.80 \pm 3.62^{\mathrm{b}}$ & $94.20 \pm 3.98^{\mathrm{a}}$ \\
\hline $\mathrm{M}_{80} \mathrm{G}_{20}$ & $80.33 \pm 6.36^{\mathrm{a}}$ & $85.00 \pm 3.46^{\mathrm{ab}}$ & $88.10 \pm 2.88^{\text {abc }}$ & $87.90 \pm .61^{\mathrm{b}}$ & $88.10 \pm 1.78$ \\
\hline $\mathrm{M}_{75} \mathrm{G}_{25}$ & $89.00 \pm 1.53^{\text {ab }}$ & $90.67 \pm 2.33^{\text {abc }}$ & $91.00 \pm 1.73$ & $90.10 \pm 1.12^{\mathrm{b}}$ & $91.42 \pm 1.58^{\mathrm{a}}$ \\
\hline $\mathrm{M}_{70} \mathrm{G}_{30}$ & $79.33 \pm 0.88^{\mathrm{a}}$ & $84.33 \pm 1.76^{\mathrm{b}}$ & $84.60 \pm 0.00^{\mathrm{b}}$ & $83.20 \pm 0.00^{\mathrm{b}}$ & $84.70 \pm 0.98$ \\
\hline
\end{tabular}

Values are mean $\pm \mathrm{SD}$ of 3 replicate determinant, $\mathrm{n}=3$; values bearing different superscripts (a,b,c) in the same rows are significantly (p<0.05) different. KEY: $M_{100}=\left(\right.$ Control), $M_{95} G_{5}=95 \%$ millet flour: $5 \%$ ginger flour $M_{90} G_{10}=90 \%$ millet flour: $10 \%$ ginger flour, $M_{85} G_{15}=85 \%$ millet flour: $15 \%$ ginger flour, $\mathrm{M}_{80} \mathrm{G}_{20}=80 \%$ millet flour: $20 \%$ ginger flour, $\mathrm{M}_{75} \mathrm{G}_{25},=75 \%$ millet flour: $25 \%$ ginger flour, $\mathrm{M}_{70} \mathrm{G}_{30}=70 \%$ millet flour: $30 \%$ ginger flour. Where, $\mathrm{M}=$ Millet, $\mathrm{G}=$ Ginger

\section{White Blood Cells count of experimental albino rats fed fermented millet flour supplemented with ginger powder}

White Blood Cell (Leucocytes) are the cells of the immune system that are involved in protecting the body against both infectious disease and foreign invaders. Leucocytes are found throughout the body, including the blood and lymphatic system. Immunity depends on WBC. The result from (Table 5) shows that the WBC increased from day 3 to day 14 . White blood cells increases when there is a problem unlike the PCV and RBC. At day 21 the WBC increased because it's mobilizing other cells like the monocytes, lymphocytes, eosinophils and basophils to fight. Elevation of WBC in diabetic rats is an indication of inflammation or tissue damage.

At day 28 the WBC revealed the diet was able to function well in the experimental rats. The control sample was unstable because of the absence of ginger in the diet. This report agrees with the report of [24] that worked on haematological parameters of alloxan- induced diabetic rats treated with leaf essential oil of Hoslundia opposite.

\section{Body weights of experimental albino rats fed fermented millet flour supplemented with ginger powder}

The experimental rats showed an increase in the body weight pattern from the initial state to day 14 including the control group and a slight decrease in body weight when alloxan was introduced on day 21 . However, there was significant $(\mathrm{p}<0.05)$ increase in body weight in all the groups on day 28 .

\section{Conclusion}

The haematological parameters showed that the White Blood Cell (WBC), Red blood cell (RBC) and Packed cell volume (PCV) increased in all the groups during the normal feeding trial from the initial today 14 while the control group (716) decreased. There was a slight increase in White blood cell (WBC) on day 21 and decrease on day 28 as compared to Red blood cell (RBC) and Packed Cell Volume (PCV) which increased slightly from day 21 to day 28 after alloxan induction which is attributed to gingerol bioactivities. Ginger was significantly effective in lowering serum glucose, in the diabetic rats compared with the control. This may be due to is gingerol present in ginger which effect anti -oxidant activity and other intrinsic biochemical triggers. The experimental rats showed an increase in the body weight pattern from the initial state to day 14 including the control group and a slight decrease in body weight when alloxan was induced on day 21.But increase in body weight in all the groups on day 28 .

\section{Acknowledgment}

All the authors acknowledged the department of Food science and Technology for support in the course of this work.

\section{Conflict of Interest}

There are no conflicts of interest among the authors. 
Citation: Eji AM, Kwagh-Hal IJ, Tartenger GA, Friday OA, Vincent U (2020) Effect of Fermented Millet Flour Ibyer Supplemented with Ginger powder on Hematological Indices and Body Weight of Wister Albino Rats. J Protein Res Bioinform 2: 013.

\section{References}

1. Oche SA (2008) Development and Quality Evaluation of Instant Ibyer-A Traditional Cereal Gruel. BSc. Thesis, Department of Food Science and Technology University of Agriculture Makurdi, Benue State.

2. Adigun NA (1997) Composition and Functional Properties of Sorghum Groundnut Flour Blends forlbyer Production. BSc. Thesis, Department of Food ScienceandTechnology Makurdi, Benue State.

3. McKeown NM, Meigs JB, Liu S, Wilson PWF, Jacques PF (2002) Whole grain intake is favorably associated with metabolic risk factors for type 2 diabetes and cardiovascular disease in the Framingham off spring Study. American Journal of Clinical Nutrition 76: 390-398.

4. Gabrovska D, Fiedlerova V, Holasova M, Maskova E, Smrcinov H (2002) The nutritional evaluation of underutilized cereals and buckwheat. Food and Nutritional Bulletin 23: 246-249.

5. Shobana S, Malleshi NG (2007) Preparation and functional properties of decorticated finger millet (Eleusine coracana). Journal of food engineering 79: 529-538.

6. Thathola A, Srivastava S, Singh G (2011) Effect of foxtail millet (Setaria italica) supplementation on serum glucose, serum lipids and glycosylated hemoglobin in type 2 diabetics. Diabetologia Croatica 40: 23-28.

7. Anju T, Sarita S (2010) Suitability of foxtail millet (Setaria italica) and barnyard millet (Echinochloa frumentacea) for development of low glycemic index biscuits. Malyasian Journal of Nutrition 16: 361-368.

8. Shukla K, Srivastava S (2014) Evaluation of finger millet incorporated noodles for nutritive value and glycemic index. Journal of Food Science and Technology 42: 1-8.

9. Shinggu CP, Tunwari BA, Gani M(2016) Finger Millet (Eleusine coracana (L.) (GAERTN)) in Sustainable Food Security in Nigeria: A Review. FUW Trend in Science and Technology Journal 1: 332-336.

10. Vanderjagt DJ, Brock HS, Melah GS, El-Nafaty AU, Crossey MJ, et al (2007) Nutritional Factors Associated with Anemia in Pregnant Woman in Northern Nigeria. The Journal Health, Population and Nutrition 2: 75-81.

11. Singh J, Dartois A, Kaur L (2010) Starch digestibility in food matrix: A review. Trends in Food Science \& Technology 21: 168-180.

12. Venn BJ, Mann JI (2013) Cereal grains, legumes and diabetes. European Journal of Clinical Nutrition 58: 1443-1461.

13. Chavan JK, Kadam SS, Beuchat LR (1989) Nutritional improvement of cereals by fermentation. Critical Reviews in Food Science \& Nutrition 28 . $349-400$.
14. Kouakou B, Alexis KKS, Adjéhi D, Marcelin D K, Dago G (2008) Biochemical changes occurring during germination and fermentation of millet and effect of technological processes on starch hydrolysis by the crude enzymatic extract of millet. Journal of Applied Sciences Research 4: 1502 1510 .

15. Inyang CU, Zakari UM (2008) Effect of germination and fermentation of pearl millet on proximate, chemical and sensory properties of instant "fura"-A Nigerian cereal food. Pakistan Journal of Nutrition 7: 9-12.

16. Ali BH, Blunden G, Tanira MO, Nemmar A (2008) Some phytochemical, pharmacological and toxicological properties of ginger (Zingiber officinale Roscoe): A review of recent research. Food Chem Toxicol 46: 409-420.

17. Nicoll R, Henein MY (2009) Ginger (Zingiber officinale Roscoe): A hot remedy for cardiovascular disease? International Journal Cardiol1 31: 408409.

18. Sengev IA, Ingbian EK, Gernah DL (2010) Sensory and storage properties of instant kunun-zaki: A non-alcoholic fermented sorghum beverage supplemented with mango mesocarp flour. Nigerian Food Journal 28: 336346.

19. Sekwati-Monang B (2011) Microbiological and chemical characterisation of ting, a sorghum-based gluten-free fermented cereal product from botswana. Ph. D. thesis, University of Alberta, Edmonton, Canada 150: 115-121.

20. Kure OA, Wyasu G (2013) Influence of Natural Fermentation, Malt Addition and Soya Fortification on the Sensory and Physicochemical Characteristics of Ibyer-Sorghum Gruel. Advances in Applied Science Research 4: 345-349.

21. Jochems CE, Vander Valk JB, Stafleu FR, Baumans V (2002) The use of fetal bovine serum: Ethical or Scientific problem? Altern Lab Arum 30: 219-227.

22. Singh R, Rana SV (2007) Protective effects of few antioxidants on liver function in rats treated with cadmium and mercury. Indian Journal of Experimental Biology 34: 177-179.

23. Coles EH (1986) Veterinary clinical pathology in ( $1^{\text {st }}$ edition). W.B. Saunders company, Pennsylvania, USA.

24. Muhammed NO, Akolade JO, Usman LA, Oloyede OB (2012) Haematological parameters of alloxan- induced diabetic rats treated with leaf essential oil of Hoslundia opposite. EXCLI Journal 11: 670-676. 


\section{di \\ Hetario}

Advances In Industrial Biotechnology | ISSN: 2639-5665

Advances In Microbiology Research | ISSN: 2689-694X

Archives Of Surgery And Surgical Education | ISSN: 2689-3126

Archives Of Urology

Archives Of Zoological Studies | ISSN: 2640-7779

Current Trends Medical And Biological Engineering

International Journal Of Case Reports And Therapeutic Studies | ISSN: 2689-310X

Journal Of Addiction \& Addictive Disorders | ISSN: 2578-7276

Journal Of Agronomy \& Agricultural Science | ISSN: 2689-8292

Journal Of AIDS Clinical Research \& STDs | ISSN: 2572-7370

Journal Of Alcoholism Drug Abuse \& Substance Dependence | ISSN: 2572-9594

Journal Of Allergy Disorders \& Therapy | ISSN: 2470-749X

Journal Of Alternative Complementary \& Integrative Medicine | ISSN: 2470-7562

Journal Of Alzheimers \& Neurodegenerative Diseases | ISSN: 2572-9608

Journal Of Anesthesia \& Clinical Care | ISSN: 2378-8879

Journal Of Angiology \& Vascular Surgery | ISSN: 2572-7397

Journal Of Animal Research \& Veterinary Science | ISSN: 2639-3751

Journal Of Aquaculture \& Fisheries | ISSN: 2576-5523

Journal Of Atmospheric \& Earth Sciences | ISSN: 2689-8780

Journal Of Biotech Research \& Biochemistry

Journal Of Brain \& Neuroscience Research

Journal Of Cancer Biology \& Treatment | ISSN: 2470-7546

Journal Of Cardiology Study \& Research | ISSN: 2640-768X

Journal Of Cell Biology \& Cell Metabolism | ISSN: 2381-1943

Journal Of Clinical Dermatology \& Therapy | ISSN: 2378-8771

Journal Of Clinical Immunology \& Immunotherapy | ISSN: 2378-8844

Journal Of Clinical Studies \& Medical Case Reports | ISSN: 2378-8801

Journal Of Community Medicine \& Public Health Care | ISSN: 2381-1978

Journal Of Cytology \& Tissue Biology | ISSN: 2378-9107

Journal Of Dairy Research \& Technology | ISSN: 2688-9315

Journal Of Dentistry Oral Health \& Cosmesis | ISSN: 2473-6783

Journal Of Diabetes \& Metabolic Disorders | ISSN: 2381-201X

Journal Of Emergency Medicine Trauma \& Surgical Care | ISSN: 2378-8798

Journal Of Environmental Science Current Research | ISSN: 2643-5020

Journal Of Food Science \& Nutrition | ISSN: 2470-1076

Journal Of Forensic Legal \& Investigative Sciences | ISSN: 2473-733X

Journal Of Gastroenterology \& Hepatology Research | ISSN: 2574-2566
Journal Of Genetics \& Genomic Sciences | ISSN: 2574-2485

Journal Of Gerontology \& Geriatric Medicine | ISSN: 2381-8662

Journal Of Hematology Blood Transfusion \& Disorders | ISSN: 2572-2999

Journal Of Hospice \& Palliative Medical Care

Journal Of Human Endocrinology | ISSN: 2572-9640

Journal Of Infectious \& Non Infectious Diseases | ISSN: 2381-8654

Journal Of Internal Medicine \& Primary Healthcare | ISSN: 2574-2493

Journal Of Light \& Laser Current Trends

Journal Of Medicine Study \& Research | ISSN: 2639-5657

Journal Of Modern Chemical Sciences

Journal Of Nanotechnology Nanomedicine \& Nanobiotechnology | ISSN: 2381-2044

Journal Of Neonatology \& Clinical Pediatrics | ISSN: 2378-878X

Journal Of Nephrology \& Renal Therapy | ISSN: 2473-7313

Journal Of Non Invasive Vascular Investigation | ISSN: 2572-7400

Journal Of Nuclear Medicine Radiology \& Radiation Therapy | ISSN: 2572-7419

Journal Of Obesity \& Weight Loss | ISSN: 2473-7372

Journal Of Ophthalmology \& Clinical Research | ISSN: 2378-8887

Journal Of Orthopedic Research \& Physiotherapy | ISSN: 2381-2052

Journal Of Otolaryngology Head \& Neck Surgery | ISSN: 2573-010X

Journal Of Pathology Clinical \& Medical Research

Journal Of Pharmacology Pharmaceutics \& Pharmacovigilance | ISSN: 2639-5649

Journal Of Physical Medicine Rehabilitation \& Disabilities | ISSN: 2381-8670

Journal Of Plant Science Current Research | ISSN: 2639-3743

Journal Of Practical \& Professional Nursing | ISSN: 2639-5681

Journal Of Protein Research \& Bioinformatics

Journal Of Psychiatry Depression \& Anxiety | ISSN: 2573-0150

Journal Of Pulmonary Medicine \& Respiratory Research | ISSN: 2573-0177

Journal Of Reproductive Medicine Gynaecology \& Obstetrics | ISSN: 2574-2574

Journal Of Stem Cells Research Development \& Therapy | ISSN: 2381-2060

Journal Of Surgery Current Trends \& Innovations | ISSN: 2578-7284

Journal Of Toxicology Current Research | ISSN: 2639-3735

Journal Of Translational Science And Research

Journal Of Vaccines Research \& Vaccination | ISSN: 2573-0193

Journal Of Virology \& Antivirals

Sports Medicine And Injury Care Journal | ISSN: 2689-8829

Trends In Anatomy \& Physiology | ISSN: 2640-7752

Submit Your Manuscript: https://www.heraldopenaccess.us/submit-manuscript 